\title{
FUEL MOISTURE DIFFERENCES IN A MIXED NATIVE AND NON-NATIVE GRASSLAND: IMPLICATIONS FOR FIRE REGIMES
}

\author{
Amy C. Livingston ${ }^{1,3}$ and J. Morgan Varner $^{2,4}$ \\ ${ }^{1}$ Wildland Fire Laboratory, Department of Forestry and Wildland Resources, \\ Humboldt State University, One Harpst Street, Arcata, California 95521, USA \\ ${ }^{2}$ Department of Forest Resources and Environmental Conservation, Virginia Tech, \\ 310 West Campus Drive, Blacksburg, Virginia 24061, USA \\ ${ }^{3}$ Current address: Trinity County Resource Conservation District, \\ \#1 Horseshoe Lane, Weaverville, California 96093, USA \\ ${ }^{4}$ Current address: USDA Forest Service Pacific Northwest Research Station, \\ Pacific Wildland Fire Sciences Laboratory, \\ 400 North 34th Street, Suite 201, Seattle, Washington 98103, USA. \\ *Corresponding author: Tel.: +1-530-623-6004; e-mail: alivingston@tcrcd.net

\section{RESUMEN}

\begin{abstract}
Non-native plants have far-reaching effects on many terrestrial ecosystems. There are several examples of non-native species altering fire regimes, either by increasing or decreasing the potential intensity and severity of fires. To investigate this phenomenon, we sampled fuel moisture content of four native grass species (Festuca californica Vasey, Danthonia californica Bol., Elymus glaucus Buckley, and Bromus carinatus Hook. \& Arn.) and four non-native grass species (Phalaris aquatica L., Cynosurus echinatus L., Arrhenatherum elatius [L.] J. Presl \& C. Presl, and Anthoxanthum odoratum L.) in northern California grasslands across the 2012 growing season. No significant differences in moisture content were found between native and non-native groups $(P=0.337)$. Across all dates, moisture content of the eight
\end{abstract}

Las plantas no-nativas tienen efectos de gran alcance en muchos ecosistemas terrestres. Hay varios ejemplos de especies de plantas no-nativas que alteran los regímenes de fuego, tanto por aumentar o disminuir la intensidad potencial y la severidad de los fuegos. Para investigar este fenómeno, nosotros muestreamos el contenido de humedad del combustible de cuatro especies de gramíneas nativas (Festuca californica Vasey, Danthonia californica Bol., Elymus glaucus Buckley, y Bromus carinatus Hook. \& Arn.) y cuatro especies de gramíneas no-nativas (Phalaris aquatica L., Cynosurus echinatus L., Arrhenatherum elatius [L.] J. Presl \& C. Presl, y Anthoxanthum odoratum L.) en pastizales del norte de California en la temporada de crecimiento de 2012. Diferencias no significativas en el contenido de humedad fueron encontradas entre grupos de nativas y no-nativas. $(P=0.337)$. A través de todas las fechas, los contenidos de humedad de las ocho especies de gramíneas difirieron significativa- 
grass species differed $(P<0.001)$. The non-native annual Cynosurus echinatus had the lowest moisture content in $\mathrm{Au}-$ gust $(21 \%)$, and fell well below ignition thresholds before the other grasses. Phalaris aquatica, an aggressive perennial non-native, had the highest moisture content for all months and differed significantly from all species for all dates $(P<0.05)$. Our results suggest that some non-native species have the capacity to alter fire behavior by either increasing or decreasing fire intensity and rate of spread. These findings reveal another way non-native species complicate restoration and management of fire-dependent ecosystems. mente $(P<0.001)$. La especie no-nativa anual Cynosurus echinatus tuvo el contenido de humedad más bajo en agosto (21\%), que fue por debajo del límite de ignición de otras gramíneas. Phalaris aquatica, una especie no-nativa perenne y agresiva, tuvo el contenido más alto de humedad en todos los meses y se diferenció significativamente de todas las especies en todas las fechas $(P<0.05)$. Nuestros resultados sugieren que algunas especies no-nativas tienen la capacidad de alterar el comportamiento del fuego incrementando o disminuyendo la intensidad del fuego y la velocidad de propagación. Estos hallazgos revelan otra forma en que las especies no-nativas complican la restauración y el manejo de ecosistemas dependientes del fuego.

Keywords: California, ecological restoration, Festuca californica, flammability, grasslands, invasive grasses, Phalaris aquatica, prescribed fire

Citation: Livingston, A.C., and J.M. Varner. 2016. Fuel moisture differences in a mixed native and non-native grassland: implications for fire regimes. Fire Ecology 12(1): 73-87. doi: 10.4996/ fireecology. 1201073

\section{INTRODUCTION}

Non-native plant invasions are responsible for a broad range of ecological effects, including the alteration of fire regimes (Brooks 1999, Davies and Nafus 2012, McDonald and McPherson 2013). In extreme cases, non-native plant invasions may cause community level changes, or even complete transformations of ecosystems by either increasing or decreasing the prevalence of fire (Mack and D’Antonio 1998, Brooks et al. 2004). For example, where non-native grasses invade desert shrubland, they create a novel fuel source that has dramatic consequences for these ecosystems (Brooks 1999, D’Antonio 2000, Davies and Nafus 2012). In cases in which non-native species differ only subtly from native species in the communities that they invade, they may have small effects on biomass, moisture content, or other fuel properties, causing sub- tle changes to fire regimes (Mack and D'Antonio 1998, D'Antonio 2000, Brooks 2008, McGranahan et al. 2013).

Several examples of changes to fuelbed properties resulting from non-native species invasions have been described (Brooks et al. 2004, Brooks 2008). By increasing horizontal fuel continuity and biomass, cheatgrass (Bromus tectorum L.) has increased the spread rate and frequency of fire in sparsely vegetated areas of western North America, creating a feedback between the invasive grass and fire (D'Antonio and Vitousek 1992, D'Antonio 2000, Brooks et al. 2004). This grass-fire cycle has resulted in the loss of native shrubsteppe vegetation over vast areas of the western United States, and has shortened the fire return interval from 50 to 100 years, to only three to five years between fires (D'Antonio 2000, Davies and Nafus 2012). The invasive red brome (Bromus madritensis ssp. rubens 
Husn.) has caused similar changes to fire regimes in the Mojave Desert, USA, threatening native plants and altering habitat and food plants of the endangered desert tortoise (Gopherus agassizii Cooper; Brooks and Esque 2002). Two invasive grasses in south Florida slash pine (Pinus elliottii Engelm. var. densa Little \& K.W. Dorman) savannas, cogongrass (Imperata cylindrica [L.] P. Beauv.) and silk reed (Neyraudia reynaudiana [Kunth.] Keng), alter fuelbed properties due to their large biomass relative to native species, resulting in increased fire intensity harmful to native species (Platt and Gottschalk 2001). Similarly, in arid and semi-arid parts of the world, buffelgrass (Pennisetum ciliare [L.] Link) dramatically increases fuel loads leading to greater fire intensity, also to the detriment of native species (McDonald and McPherson 2013). The invasion of gamba grass (Andropogon gayanus Kunth.), in northern Australia, increased fuel loads resulting in a six-week extension of severe fire season (Setterfield et al. 2013). In other cases, non-natives diminish aspects of fire regimes including spread or intensity. The Brazilian pepper tree (Schinus terebinthifolius Raddi) invades fire-maintained Florida prairies at such high densities that it suppresses understory fuels necessary to maintain fire (Mack and D'Antonio 1998), as has Chinese tallow (Triadica sebifera [L.] Small) in temperate grasslands of North America (Bruce et al. 1997).

Fire behavior in grasslands is affected by particle properties of live fuels including foliar moisture content, surface area-to-volume ratio, and heat content (Brooks et al. 2004, Dibble et al. 2007, Davies and Nafus 2012, McGranahan et al. 2013). The moisture content of the species composing a fuelbed determines whether it functions as a heat sink or a heat source influencing the ignitability and combustibility of fuels, and the spread rate and intensity of fire (Chuvieco et al. 2004, Dimitrakopoulos et al. 2010). By decreasing the moisture content of the fuelbed it has invaded, cheatgrass has expanded the fire season by approximately 30 days in southeastern Oregon, USA (Davies and Nafus 2012). Conversely, the invasion of the cool season $(\mathrm{C} 3)$ grass tall fescue (Festuca arundinacea Schreb.) into tallgrass prairie composed of native warm season (C4) species decreases fire intensity and spread (McGranahan et al. 2013). This dampening effect is due to the asynchronous phenology of tall fescue compared to the native species, which results in its higher moisture content during the fire season (McGranahan et al. 2013). Similarly, the high moisture content of invasive iceplant (Carpobrotus edulis [L.] L. Bolus) decreases the ignitability of the native, fire-dependent chaparral (D'Antonio 2000, Brooks et al. 2004).

Several non-native grass species have successfully invaded the coastal grasslands and neighboring oak savannas and woodlands of the Bald Hills in Redwood National Park, California, USA (Sugihara and Reed 1987, Arguello 1994). Frequent, low intensity fires are necessary for the persistence of these fire-dependent ecosystems that are otherwise susceptible to encroachment from native conifers and potential shift to conifer forest (Sugihara and Reed 1987, Agee 1993, Fritschle 2008, Engber et al. 2011). In the Bald Hills and elsewhere in the Pacific Northwest (Tveten and Fonda 1999, Hosten et al. 2006, Engber and Varner 2012), managers rely on prescribed fires for the maintenance of these communities, adding to the importance of understanding the effects that non-native species may have on these fire regimes.

To add to the collective understanding of the ways non-native grass species may influence fire regimes, we measured grass fuel properties in a California grassland heavily invaded by a diversity of non-native grasses. We sampled the moisture content and stature of eight dominant native and non-native grass species. We compared moisture content between native and non-native groups, among species, and across collection periods for four 
native and four non-native grasses during the 2012 growing season. Our findings have implications for California grasslands and perhaps more broadly, where mixtures of native and non-native grasses occur.

\section{METHODS}

\section{Study Site}

We collected fuels in the grasslands of the Bald Hills of Redwood National Park, in northwestern California, USA ( $41^{\circ} 12^{\prime} \mathrm{N}, 123^{\circ}$ 54' W; Figure 1). The Bald Hills span a broad, five-kilometer long ridge dividing the Klamath River and Redwood Creek watersheds. The Bald Hills contain 1700 ha of grasslands and oak (primarily Quercus garryana Hook.) savannas and woodlands composed of a mix of native and non-native herbaceous species. The climate is mediterranean, with approximately $90 \%$ of the approximately $200 \mathrm{~cm}$ of precipitation falling as rain between October and May. A strong Pacific Ocean influence causes summer fog that usually clears by late morning. The mean daily high temperature in July

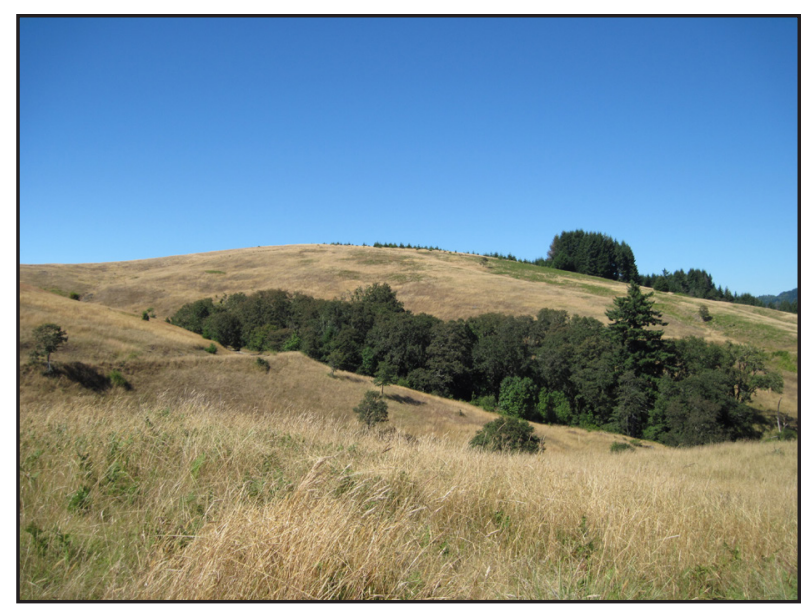

Figure 1. Moisture content of native and non-native grasses were sampled at Williams Ridge in the Bald Hills of Redwood National Park, California, USA. The grasslands in the foreground are a mixture of native and non-native grass species, including several of the study species. is $25^{\circ} \mathrm{C}$, with temperatures rarely exceeding $38^{\circ} \mathrm{C}$ (USDI Redwood National Park 1992).

Fires in the Bald Hills were historically caused by both lightning ignitions and by $\mathrm{Na}-$ tive American burning (Agee 1993). Native Americans routinely burned the prairies and woodlands of the Bald Hills to favor plants for human consumption, sustain basketry materials, and attract wildlife (Underwood et al. 2003, Hosten et al. 2006). European settlers arrived in the late 1860 s and began grazing sheep and cattle (Underwood et al. 2003). A study from the early twentieth century indicates that, prior to European settlement, the prairies in the Bald Hills were likely dominated by native bunchgrasses, including species of Danthonia DC., Stipa L., Melica L., Poa L., and Festuca L., mixed with annual and perennial clovers (Trifolium L. spp.) (Davy 1902). Livestock grazing in the Bald Hills continued until 1978 and had a dramatic influence on vegetation. Many non-native grass and forb species were introduced as a result of grazing and have since become widespread (Saenz and Sawyer 1986, Sugihara et al. 1987, Grenier 1989). Fire suppression, which began after European settlement, also contributed to a shift in species composition (Underwood et al. 2003).

By the early 1990s, tall oatgrass (Arrhenatherum elatius [L.] J. Presl \& C. Presl), sweet vernal grass (Anthoxanthum odoratum L.), and dogtail (Cynosurus echinatus L.), were among the most dominant non-native species in the grasslands of the Bald Hills (Saenz 1983, Grenier 1989, Arguello 1994). Harding grass (Phalaris aquatica L.) was first detected in the park at this time, and quickly spread throughout the grasslands. Due to its tendency to form dense monocultures, Harding grass is currently the most problematic non-native grass in the park (S. Samuels, National Park Service, Orick, California, USA, personal communication). A prescribed fire program was initiated in the early 1990s to control invasion of the native conifer Douglas-fir (Pseudotsuga men- 
ziesii [Mirb] Franco var. menziesii) and to maintain native herbaceous species richness (Underwood et al. 2003). The fire season for the area spans early summer to late fall; prescribed fires typically occur between September and early November each year.

To compare fuel moisture of native and non-native grasses, we sampled eight grass species during the 2012 growing season. We concentrated sampling over 131 days from 6 June through 14 October 2012 within in a 150 $\mathrm{m} \times 150 \mathrm{~m}$ area within the East and West Williams Ridge burn units. The study site is representative of a typical grassland in the Bald Hills, based on the species composition (Figure 1). Away from edges of oak woodlands and conifer forest, grasslands in the Bald Hills are largely devoid of woody fuels (Engber et al. 2011). The burn units were $22.5 \mathrm{~km}$ inland from the Pacific Ocean at an elevation of 730 m. Both units were located within $1 \mathrm{~km}$ of a remote automated weather station (RAWS) located at Schoolhouse Peak (SHUC1). Williams Ridge West was burned in 1992, and both units were burned in 1995, 1997, 2005, and on 19 October 2012. One study species, Harding grass, was not abundant in the Williams Ridge burn units so a population was selected in a separate burn unit within $1 \mathrm{~km}$ of the other species. Following sampling in June, the initial patch of Harding grass selected for our study was accidentally sprayed with herbicide. For all other months, sampling occurred approximately $10 \mathrm{~m}$ downslope of the original population.

\section{Field Data Collection}

The grasslands in the Bald Hills are dominated by perennials, though several annual grasses are also present, the majority of which are non-native (Livingston 2014). The eight species chosen for this study were selected based on their prevalence. The native species studied were California brome (Bromus californica Hook. \& Arn.), blue wildrye (Elymus glaucus Buckley), California oatgrass (Danthonia californica Bol.), and California fescue (Festuca californica Vasey) (Figure 2). The non-native species studied were Harding grass, dogtail, tall oatgrass, and sweet vernal grass (Figure 2). All study species are perennial with the exception of dogtail, a small-statured annual, and all are physiologically similar, cool season (C3) species. All of the species have a generally cespitose, or at least tufted, growth form, and several are sometimes also rhizomatous. Harding grass is rhizomatous, and sweet vernal grass and tall oatgrass are sometimes rhizomatous. Blue wildrye sometimes has rhizomes or short stolons. California fescue is an exceptionally robust native grass, with a clump-like growth form that retains abundant dead thatch. It is considered important in regional fire regimes because it is a highly flammable native species (Hastings et al. 1997, Engber et al. 2011).

Grass fuel moisture sampling occurred throughout the growing season, once each month during June to August of 2012, and at two week intervals during the peak of the prescribed fire season starting in September. Sampling ended one week prior to the prescribed burning of Williams Ridge East and West on 19 October 2012. We sampled fuel moisture via clipping stalks and leaves approximately $1 \mathrm{~cm}$ from the ground surface. We placed collected biomass in pre-weighed 15 $\mathrm{cm} \times 23 \mathrm{~cm}$ polyethylene bags. Seven samples were collected for each species on each sampling date. Samples ranged from $20 \mathrm{~g}$ to $60 \mathrm{~g}$ (oven-dry weight), depending on the size of the species. With the exception of California fescue, samples included live and, as the season progressed, cured material of the current year's growth. Due to its unique habit, the large bunchgrass California fescue was sampled by cutting a section from the outside edge of the bunch toward the center, which included dead thatch connected to the plant and live plant material. We also recorded heights for each species on each sampling date to track 


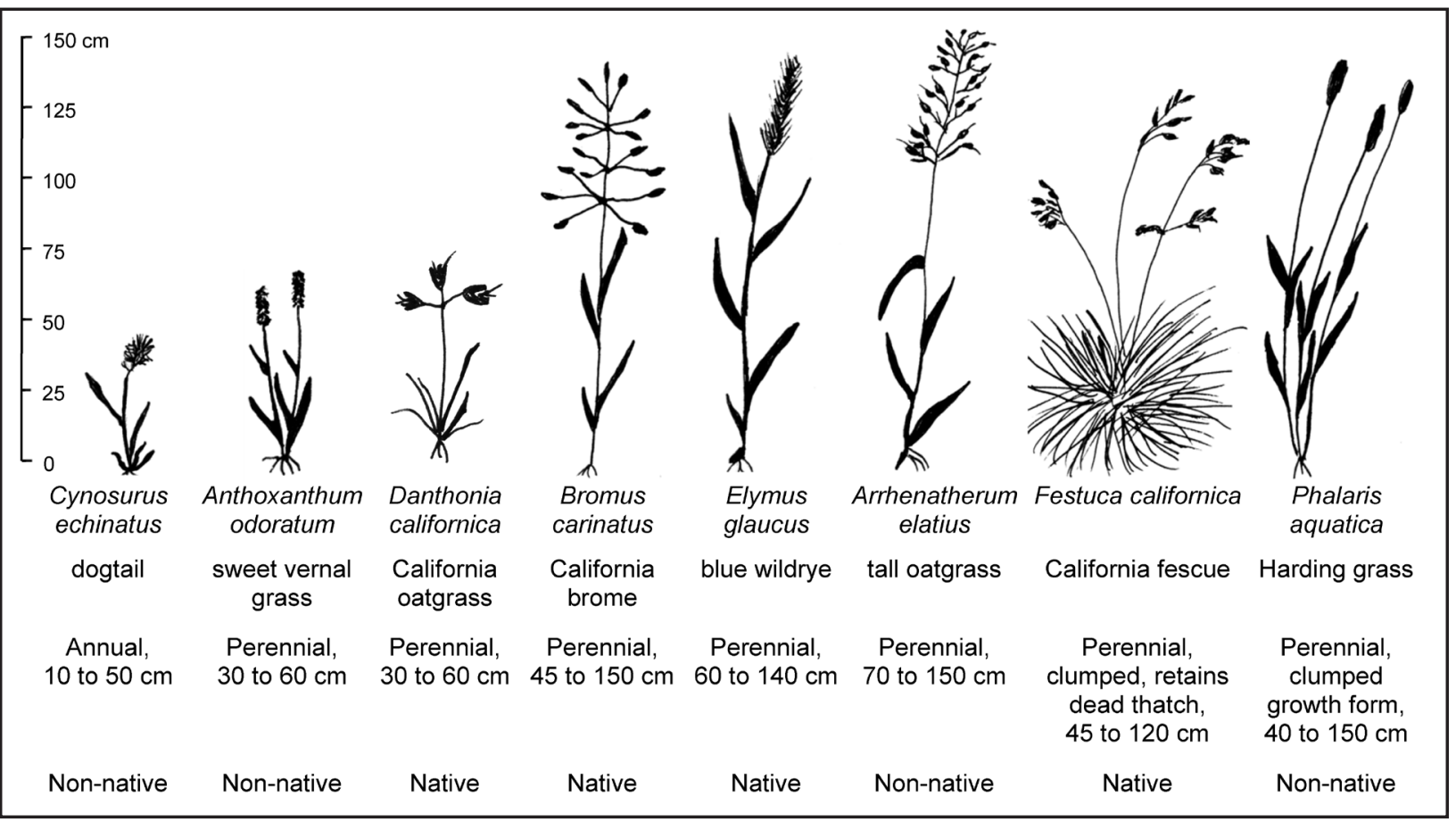

Figure 2. Grass species sampled for foliar moisture content during the 2012 fire season in the Bald Hills of Redwood National Park. We selected four native and four non-native grass species to study their effects on the fuelbed.

relative differences in stature throughout the growing season. After collection, we transported all grass samples directly to the laboratory. With the exception of 14 October, when the weather was partly cloudy, sampling occurred on clear days between $1130 \mathrm{hr}$ and $1700 \mathrm{hr}$. Our sampling window was slightly longer than what others have considered ideal for minimizing variation in environmental conditions (Countryman 1974, Rice 1989, Agee et al. 2002); however, the large amount of sampling necessitated expanding the window. To determine wet weight, we weighed each specimen inside the pre-weighed polyethylene bag, and then subtracted the bag weight to determine actual wet weight. After weighing, we dried grasses in a convection oven at $70^{\circ} \mathrm{C}$ for $48 \mathrm{~h}$ until dry weight stabilized. We weighed all dry samples to determine dry weight (gravimetric basis).

The grass populations sampled, for all species except Harding grass, were spread throughout a $150 \mathrm{~m} \times 150 \mathrm{~m}$ area; the Harding grass population was less than $1 \mathrm{~km}$ away. Species were sampled in the same order on each date to maximize efficiency and maintain consistency. To evaluate the effect that time of collection had on fuel moisture values, we sampled from a subset of four species every two hours over an eight-hour period, on a single day on 10 October 2012. Two native species, California fescue and blue wildrye, and two non-native species, Harding grass and sweet vernal grass, were sampled. We sampled these species at two-hour intervals between $0900 \mathrm{hr}$ and $1700 \mathrm{hr}$. Due to the small amount of Harding grass remaining at our study site, only two to three samples of this species were collected at each interval. The number of samples collected for the other species depended upon the abundance of easily accessible material; three samples were collected for blue wildrye, four for California fescue, and five for sweet vernal grass. Throughout the eight-hour sampling period, the air temperature ranged from $12.8^{\circ} \mathrm{C}$ to $16.7^{\circ} \mathrm{C}$, 
relative humidity ranged from $62 \%$ to $80 \%$, and wind speeds ranged from $3.2 \mathrm{~km} \mathrm{~h}^{-1}$ to $9.7 \mathrm{~km} \mathrm{~h}^{-1}$.

\section{Data Analysis}

To evaluate differences in grass moisture content (\%) among the eight grass species, across the six sampling dates, and for the species and date interaction, we used a two-way analysis of variance (ANOVA). A two-way ANOVA was used instead of a time series analysis because of the small number of sampling dates, and due to the fact that the dates increased in frequency during peak fire season. Residual plots were evaluated and assumptions for normality and homogeneity of variance were met (Zar 1999). When differences were detected, we used the conservative Tukey HSD (Honest Significant Difference) multiple comparison test to compare all pairwise differences. Significance for all statistical analyses was determined using $\alpha=0.05$.

A hierarchical, linear mixed effects model with binomial error structure and logit link was used to evaluate differences among the mean moisture content of the native species and non-native species across all sampling dates, with the eight species nested into a native or non-native group type. Our model included a single fixed effect categorical variable for native or non-native species. Moisture content was the response variable. Sampling date and species were designated as random effects (Crawley 2013). Residual plots were assessed, revealing that the model met the assumptions for normality and homogeneity of variance (Zar 1999). Diurnal sampling results were evaluated by comparing mean and standard error of moisture content of each species at each interval over the eight-hour sampling period.

\section{RESULTS}

The mean monthly moisture content of the native grass species did not differ significantly from the non-native grasses across all six sampling dates (fixed-effects ANOVA; $F_{1,6}=$ $1.088, P=0.337)$. There was, however, a significant difference in moisture content among the eight species across the sampling dates $\left(F_{47}\right.$ $=179.4, P<0.001)$. Harding grass had higher mean moisture content on all sampling dates compared to the other seven species (Tukey HSD $P<0.05)$; it was the only species that differed from all other species across all sampling dates. The mean moisture content of Harding grass was $303 \%$ in June while the mean moisture content of all other species ranged from $107 \%$ to $266 \%$. As the growing season progressed, the gap between mean moisture content of Harding grass and all other species widened (Figure 3). On 25 September, when Harding grass was driest, its mean moisture content was still more than double that of California fescue (116\% compared to $49 \%$ ). The mean moisture content of Harding grass was several times higher than all the other species, which ranged from only $6 \%$ to $19 \%$.

The non-native dogtail had significantly lower mean moisture content than all other species except sweet vernal grass and California oatgrass (Tukey HSD $P<0.05$ ). On $6 \mathrm{Au}-$ gust, the mean moisture content of dogtail and California oatgrass were $21 \%$ and $42 \%$, respectively. They were the only species to fall below an ignition threshold at this date, assuming a conservative moisture of extinction value of 55\% (Dimitrakopoulos et al. 2010). Mean moisture content of all other species ranged from $57 \%$ to $182 \%$ in August. By the next sampling date, 5 September, the mean moisture content for all other species except Harding grass and California fescue ranged from $6 \%$ to $29 \%$ (Figure 3 ) and fell below a probable threshold for moisture of extinction. On this date, the mean moisture content of California fescue was $59 \%$, while the moisture content of Harding grass remained much higher with a mean of $117 \%$.

The moisture content of the grasses throughout the growing season varied to dif- 


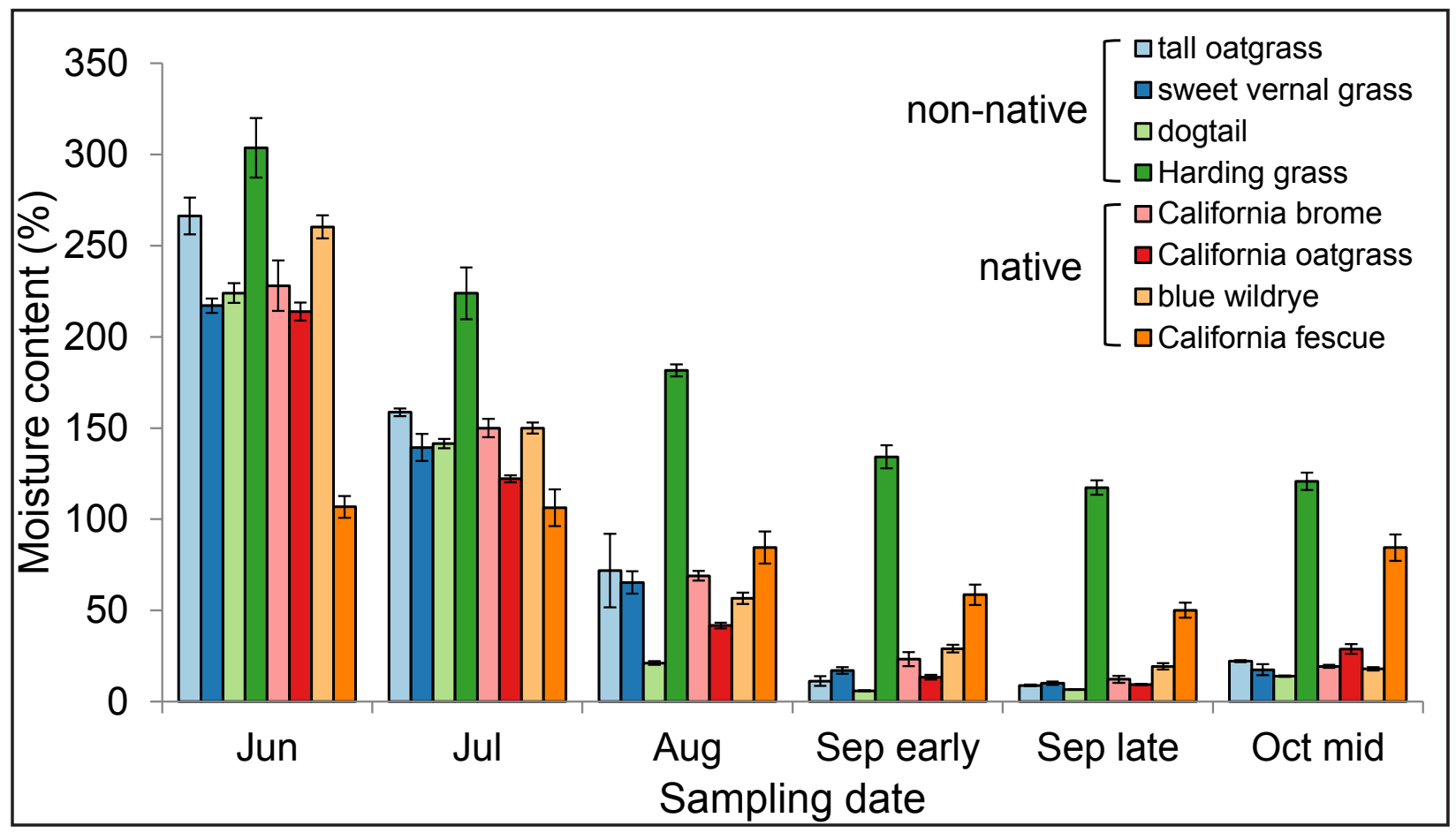

Figure 3. Moisture content of four native (pink through orange) and four non-native (blue through green) grass species across the 2012 fire season in the Bald Hills of Redwood National Park. Error bars represent SE.

ferent extents. The native California fescue's mean moisture content varied the least across the sampling period. Its mean moisture content was highest in June (107\%) and lowest in late September $(50 \%)$. Harding grass had the next smallest amount of change across the season, from a high average of $304 \%$ to a low of $117 \%$. Dogtail had the largest range of mean moisture content values, ranging from a high of $224 \%$ in June, to a low of $6 \%$ in early September.

The moisture content of all eight grass species followed the seasonal precipitation trends for 2012, and a significant interaction was found between species and date $\left(F_{288}=179.4\right.$, $P<0.001)$. Precipitation in 2012 was higher than the 10-year average, according to data from the Schoolhouse Peak weather station, and the moisture content values likely reflect this. Precipitation during March was double the 10-year average, and April and June had slightly more precipitation than average.
During July, $26 \mathrm{~mm}$ of rain fell, nearly twice the 10-year average. Mean moisture content of all species was highest in June and July when precipitation was still occurring (Figure 4), and declined in August after rainfall ended for the season. The moisture content of all species except blue wildrye increased by the 14 October sampling date after a cumulative $10.4 \mathrm{~mm}$ of rain had fallen. Mean moisture content of blue wildrye was $19 \%$ in late September and $18 \%$ on 14 October.

Results from sampling diurnal moisture content confirmed that influence from weather variation was minimal after late morning (1100 hr) and that our fuel sampling window (1130 hr to $1700 \mathrm{hr}$ ) was appropriate for these grasses. Three of the four species we sampled showed a large decrease in moisture content between the $0900 \mathrm{hr}$ and $1100 \mathrm{hr}$ morning collection times. Between $1100 \mathrm{hr}$ and $1700 \mathrm{hr}$, the moisture content of all species sampled were relatively stable. Data from diurnal sam- 


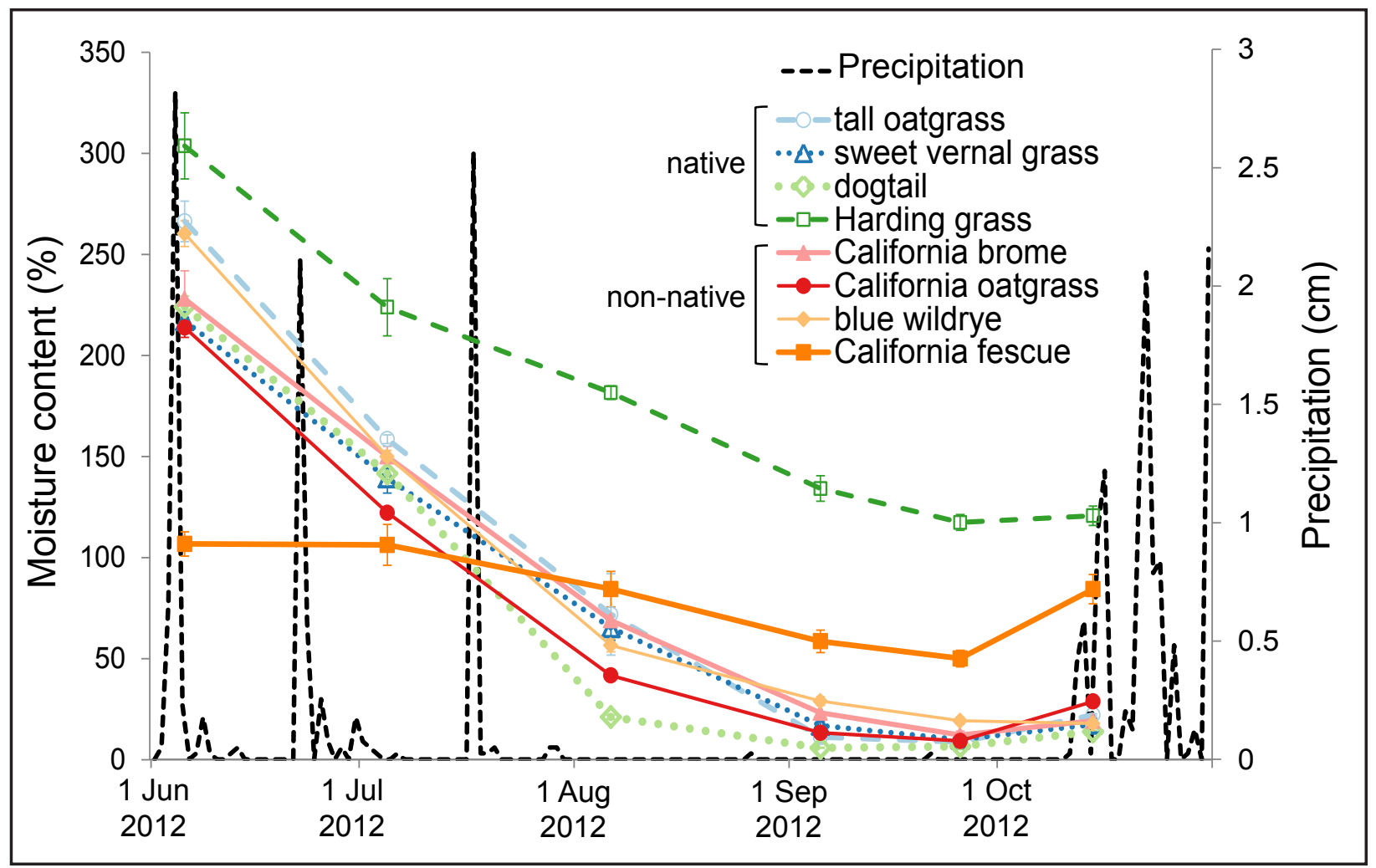

Figure 4. Moisture content of four native (solid symbols and lines) and four non-native (open symbols and broken lines) grass species followed seasonal precipitation trends during the 2012 fire season in the Bald Hills of Redwood National Park. Moisture content was highest in June and July and declined in August when rainfall ended. Moisture contents increased in October after $1 \mathrm{~cm}$ of rain. A prescribed burn on 19 October 2012 ended sampling.

pling on 10 October were not analyzed with the data we collected regularly between 1130 $\mathrm{hr}$ and $1700 \mathrm{hr}$ throughout the growing season.

\section{DISCUSSION}

In many ecosystems, non-native grass species have been implicated in altering fire regimes, particularly where they invade areas with no native analogues (Brooks 1999, D'Antonio 2000, Brooks et al. 2004, Brooks 2008). In the Bald Hills, potential effects on the fire regime are complex, depending to a large extent on the degree to which the composition of the fuelbed has shifted with species invasions. Of the four non-native species that we studied, one of these, Harding grass, sustained high moisture content throughout the growing season and may act to delay ignition and dampen fire spread and intensity. In contrast, the non-native annual dogtail might decrease fuel moisture levels and increase their ignitability earlier in the fire season compared to most native perennial species. Two of the non-native species that we studied, sweet vernal grass and tall oatgrass, did not differ from the native species' moisture contents.

The only annual species that we studied, the non-native dogtail, had significantly lower moisture content than all other study species across all dates except for the non-native sweet vernal grass and the native California oatgrass, which also had relatively low moisture content. These three grasses are relatively small-statured (Figure 2). Dogtail reached its maximum height early and flowered quickly, fitting with its sharp decline in moisture content early in the growing season. After this 
species senesced (at approximately the end of July), samples of this species contained primarily dead material. California oatgrass is unique among the study species because, when its seeds are mature, the dried culms detach from the still-green basal leaves and fall on the ground. This occurred between the 6 August and 5 September sampling dates, when the moisture content for this species decreased sharply (Figure 3). For the remainder of sampling dates, both basal leaves and detached culms were included in samples. With the exception of Harding grass, the moisture content of the four larger perennials (Figure 2; the native California brome, blue wildrye, California fescue, and the non-native tall oatgrass) did not differ significantly from each other.

Due to its substantial mass and the dead fuel it retains, California fescue is considered a highly flammable fuel in oak woodland understories, capable of burning with high intensity where it is dominant (Hastings et al. 1997). In the Bald Hills, this species is considered to be an exceptional fuel, contributing to the fast moving, low intensity fires that prohibit young conifers from invading (Engber et al. 2011). We did not find a difference in the moisture content for California fescue across all sampling months compared to the other robust perennial species (with the exception of Harding grass, which was significantly higher). California fescue's reputation as an exceptional fuel source is partially dependent on its mass. Oak woodland understory dominated by California fescue in the Bald Hills had more than double the herbaceous mass of mixed grasslands, and a positive correlation was found between herbaceous fuel mass and surface fire temperatures in this ecosystem (Engber et al. 2011). Given the large amounts of dead thatch that this species retains, much of which is held close to the ground, it may have responded differently to the wetter than average year compared to the other species, and perhaps it had higher moisture content values than it otherwise would have. Likewise, the low variability in moisture content of this species may also be related to its growth form and the dead thatch it retains.

In stark contrast to the patterns in moisture content found in the seven other species, the non-native Harding grass had much higher moisture content than all other species throughout the growing season. Even on its driest sampling date, the moisture content of Harding grass was still more than double a probable value for moisture of extinction. One caveat to our findings is that limited pilot sampling on 28 June 2013 confirmed that the new Harding grass location we moved to in July was more mesic than our original Harding grass location. Mean moisture content for Harding grass at our initial location was 239\% compared to $290 \%$ at the location we moved to (a $18 \%$ difference relative to the new location). Harding grass was also sampled from two other locations in the Bald Hills that had mean moisture contents of $201 \%$ and $203 \%$, a $31 \%$ and $30 \%$ difference relative to our new Harding grass location, respectively. On 25 September 2012, however, the relative difference between six of the grass species and Harding grass ranged from $84 \%$ to $95 \%$ (relative to Harding grass), and the relative difference between Harding grass and California fescue was $58 \%$ (relative to Harding grass). It is unlikely that sampling in the more mesic location would negate the general pattern we reported, as the magnitude of difference between Harding grass and the other species was so large. Additionally, at our sampling location, Harding grass culms were noticeably greener late into the fall compared to the other co-occurring species. Although the inferences we are able to make from a single study location are somewhat limited, the patterns that we observed are still noteworthy.

The high moisture content of Harding grass may have implications for prescribed fire. In the Bald Hills, known Harding grass infestations totaled approximately 33 ha in 2012, with infestation densities ranging from scattered individuals to dense monocultures (S. Samuels, personal communication). De- 
pending on the density and extent of Harding grass infestations, combined with burn-day weather conditions of wind speed and relative humidity, as well as topographic position, this species may act to dampen fire intensity. Because of the other threats it poses to native species, park managers are currently trying to eradicate this species from the Bald Hills. The potential impediments that this species may pose to prescribed burning may serve as additional motivation for managers to eradicate this species from fire-dependent ecosystems.

The relative dominance of non-native species in a fuelbed will have a significant impact on the overall contribution of the species on the fire regime. A survey of understory vegetation in the oak woodlands of the Bald Hills found that the mean cover of dogtail was $9 \%$ (Livingston 2014). Comparatively, mean cover for tall oatgrass, sweet vernal grass, California brome, blue wildrye, and California fescue in oak woodland understories ranged from only $1 \%$ to $4 \%$. California oatgrass occurred in woodland understory sampling rarely, and Harding grass was not detected in this survey (Livingston 2014). California oatgrass is one of the more common native grass species in the prairies of the Bald Hills, however, and Harding grass has primarily invaded prairies. Although its overall cover was low in the oak woodland understory survey, California fescue is dominant in several areas of the Bald Hills (Engber et al. 2011), and where it does occur, its cover is generally very high. The non-native species that we studied commonly invade other grasslands and woodlands ecosystems in the Pacific Northwest (Dennehy et al. 2011, Stanley et al. 2011) and elsewhere (Hitchcock 1971), making the results of this study relevant at broader geographic scales.

The non-native dogtail and the native California oatgrass were the first species to fall below a probable threshold for moisture of extinction, and the moisture content of dogtail was much lower than all other study species on 6 August. Depending on the density of dogtail, it may decrease fuel moisture levels and increase ignitability earlier in the fire season. Although the moisture content of California oatgrass was twice that of dogtail in August (21\% and $42 \%$ respectively), California oatgrass had possibly cured sufficiently to be ignitable based on the more conservative values for moisture of extinction estimated for grass species (Burrows et al. 1991). Although still common in the Bald Hills, California oatgrass is patchily distributed in the prairies, and it is thought to be less dominant now than it was historically (cf. Davy 1902). Potential effects on the fire regime in the prairies of the Bald Hills caused by dogtail may be reduced because of the diminished dominance of California oatgrass. Although the species selected for this study are among the most dominant, there are several other grass species in the Bald Hills, including many other non-native annuals: oats (Avena L. spp.), bromes (Bromus L. spp.), rattail six-weeks grass (Festuca myuros L.), brome fescue (Festuca bromoides L.), and silver hair grass (Aira caryophyllea L.), and a few native annuals (e.g., Poa howellii Vasey \& Scribn), that we did not study (Livingston 2014). If other annual species have moisture content values similar to those that we observed for dogtail, they might have an additive effect on the ignition potential of fuel early in the fire season. As our study was not comprehensive, speculation on the net effects of fuel moisture change with invasion is difficult.

The trend we observed in this study for the seasonal curing of grass is consistent with other research from the western United States. In quaking aspen (Populus tremuloides Michx.) woodlands, the moisture content of a composite of grass species steadily decreased until fall rains occurred and basal leaves of perennials greened up, and moisture content increased (Brown et al. 1989). Composite samples of grass and grass-like plants from the understory of upland Douglas-fir communities showed a similar drying pattern when early and late sea- 
son moisture content was compared (Agee et al. 2002). Large differences in the moisture content among individual native herbaceous species have been reported from quaking aspen understories in Wyoming (Brown et al. 1989) as well as from the Great Lakes region (Loomis et al. 1979).

The relative changes in moisture content that we observed at two-hour intervals during our sampling window of $1130 \mathrm{hr}$ and $1700 \mathrm{hr}$ are consistent with relative changes reported for crown foliage and forest floor fuel moisture (Agee et al. 2002, Banwell et al. 2013). Our diurnal sampling showed that the early morning (between $0900 \mathrm{hr}$ and $1100 \mathrm{hr}$ ) changes in fuel moisture were, however, dramatically greater than changes observed for these other fuel types. The moisture content of one-year-old foliage in the Pacific Northwest varied only $4 \%$ to $12 \%$, depending on species, when sampled at two-hour intervals from 1000 hr to $1600 \mathrm{hr}$ (Agee et al. 2002). Over a twenty-four-hour period in the Lake Tahoe Basin, moisture content of forest floor fuels (1 hr woody fuels, litter, and pine cones) underwent a similar $3 \%$ to $11 \%$ relative change in moisture content (Banwell et al. 2013). The large decrease in moisture content that we observed for three of our four study species (relative change ranged from $40 \%$ to $84 \%$ ) likely resulted from the clearing of coastal fog often present in the morning at our study site, which increases nocturnal moisture content and slows morning drying. Not surprisingly, herbaceous fuels like grasses are much more responsive to ambient moisture.

A definitive value for moisture of extinction - the fuel moisture content at which fire will not spread, or when the probability of ignition is $1 \%$-has not been widely agreed upon for grasses (Dimitrakopoulos et al. 2010). Fire ignition and spread was difficult when moisture content approached 35\% for spinifex grass fuel in Australia, primarily hard spinifex (Triodia basedowii E. Pritz.) and soft spinifex (Plectrachne schinzii Henrard) (Burrows et al. 1991). Laboratory ignition tests for grass samples consisting primarily of Imperata cylindrica in Indonesia found moisture of extinction to be $40 \%$ for dead grass and $44 \%$ for live grass (de Groot and Wang 2005). Recent field experiments in Greece estimated the moisture of extinction for slender oat $(A v-$ ena barbata Link.) at 55.5\% (Dimitrakopoulos et al. 2010). Day of burn weather and topographic conditions also influence moisture of extinction, particularly wind speed, which has been shown to overwhelm ignition potential when fuel moisture is high (Dimitrakopoulos et al. 2010). Morphological properties of individual species, including size of culms and leaves, as well as residual dead fuels (not part of our sampling) may also increase the probability of ignition and affect spread, particularly in the robust bunchgrasses (i.e., California fescue).

The potential effects that non-native grass species have on the fire regime in the Bald Hills are complex. The non-native annual dogtail may decrease fuel moisture levels, increasing the ignitability of fuels early in the fire season via its early senescence, as has been observed in other non-native grasses (Brooks 1999, Davies and Nafus 2012). In contrast, where Harding grass invades and occurs at high densities, it may serve as an impediment to fire throughout the fire season via its high, stable moisture content. Only one other invasive grass species, tall fescue, has been shown to have a dampening effect on fire in tallgrass prairies, and this is caused by its asynchronous physiology (McGranahan et al. 2013). Our results may be the first that identify a large magnitude difference in moisture content between cool season native and non-native grass species in a fuelbed. Although the effects of individual non-native species may be moderated by the characteristics and density of other species in the fuelbed, our study demonstrates their capacity for altering ecosystem processes and potentially complicating the restoration of fire-dependent ecosystems. 


\section{ACKNOWLEDGEMENTS}

Funding for this research was provided by the USDA McIntire-Stennis Forestry Research Program and the University of California Agriculture and Natural Resources Competitive Grants program. Field and laboratory assistance were provided by E. Asarian, K. Eldridge, and N. Hancock. Advice on statistical analysis was provided by R. Van Kirk. Comments on the design and on previous versions of the manuscript were provided by L. Arguello, E. Engber, E. Jules, and J. Kane. Managers at Redwood National Park (L. Arguello, S. Samuels, and L. Julian) graciously allowed access to study sites and provided information on site history and management. Comments and suggestions by reviewers improved the quality and clarity of the manuscript.

\section{LITERATURE CITED}

Agee, J.K., C.S. Wright, N. Williamson, and M.H. Huff. 2002. Foliar moisture content of Pacific Northwest vegetation and its relation to wildland fire behavior. Forest Ecology and Management 167: 757-766. doi: 10.1016/S0378-1127(01)00690-9

Agee, J.K. 1993. Fire ecology of Pacific Northwest forests. Island Press, Washington, D.C., USA.

Arguello, L.A. 1994. Effects of prescribed burning on two perennial bunchgrasses in the Bald Hills of Redwood National Park. Thesis, Humboldt State University, Arcata, California, USA.

Banwell, E.M., J.M. Varner, E.E. Knapp, and R.W. Van Kirk. 2013. Spatial, seasonal, and diel forest floor moisture dynamics in Jeffrey pine-white fir forests of the Lake Tahoe Basin, USA. Forest Ecology and Management 305: 11-20. doi: 10.1016/j.foreco.2013.05.005

Brooks, M.L. 1999. Alien annual grasses and fire in the Mojave Desert. Madroño 46: 13-19.

Brooks, M.L. 2008. Plant invasions and fire regimes. Pages 33-46 in: K. Zouhar, J. Kapler Smith, S. Sutherland, and M.L. Brooks, editors. Wildland fire in ecosystems: fire and nonnative invasive plants. USDA Forest Service General Technical Report RMRS-GTR-42-volume 6, Rocky Mountain Research Station, Ogden, Utah, USA.

Brooks, M.L., C.M. D’Antonio, D.M. Richardson, J.B. Grace, J.E. Keeley, J.M. DiTomaso, R.J. Hobbs, M. Pellant, and D. Pyke. 2004. Effects of invasive alien plants on fire regimes. BioScience 54: 677-688. doi: 10.1641/0006-3568(2004)054[0677:EOIAPO]2.0.CO;2

Brooks, M.L., and T.C. Esque. 2002. Alien annual plants and wildfire in desert tortoise habitat: status, ecological effects, and management. Chelonian Conservation and Biology 4: 330340.

Brown, J.K., G.D. Booth, and D.G. Simmerman. 1989. Seasonal change in live fuel moisture of understory plants in western US aspen. Pages 406-412 in: D.C. MacIver, H. Auld, and R. Whitewood, editors. Proceedings of the 10th Conference on Fire and Forest Meteorology. Forestry Canada, Petawawa National Forestry Institute, Chalk River, Ontario, Canada.

Bruce, K.A., G.N. Cameron, P.A. Harcombe. 1997. Introduction, impact on native habitats, and management of a woody invader, the Chinese tallow tree (Sapium sebiferum [L.] Roxb.). Natural Areas Journal 17: 255-260.

Burrows, N., B. Ward, and A. Robinson. 1991. Fire behaviour in spinifex fuels on the Gibson Desert Nature Reserve, Western Australia. Journal of Arid Environments 20: 189-204.

Chuvieco, E., I. Aguado, and A.P. Dimitrakopoulos. 2004. Conversion of fuel moisture content values to ignition potential for integrated fire danger assessment. Canadian Journal of Forest Research 34: 2284-2293. doi: 10.1139/x04-101 
Countryman, C.M. 1974. Moisture in living fuels affects fire behavior. Fire Management Notes 35: $10-14$.

Crawley, M.J. 2013. The R book. Second edition. Wiley, West Sussex, England, United Kingdom.

D’Antonio, C.M. 2000. Fire, plant invasions, and global changes. Pages 65-93 in: H. Mooney and R. Hobbs, editors. Invasive species in a changing world. Island Press, Washington, D.C., USA.

D'Antonio, C.M., and P.M. Vitousek. 1992. Biological invasions by exotic grasses, the grass/fire cycle, and global change. Annual Review of Ecology and Systematics 23: 63-87. doi: 10.1146/annurev.es.23.110192.000431

Davies, K.W., and A.M. Nafus. 2012. Exotic annual grass invasion alters fuel amounts, continuity, and moisture content. International Journal of Wildland Fire 22: 353-358. doi: 10.1071/ WF11161

Davy, J.B. 1902. Stock ranges of northwestern California: notes on the grasses and forage plants and range conditions. USDA Bureau of Plant Industry Bulletin 12, Washington, D.C., USA. doi: $10.5962 /$ bhl.title. 65141

de Groot, W.J., and Y. Wang. 2005. Calibrating the fine fuel moisture code for grass ignition potential in Sumatra, Indonesia. International Journal of Wildland Fire 14: 161-168. doi: 10.1071/WF04054

Dennehy, C., E.R. Alverson, H.E. Anderson, D.R. Clements, R. Gilbert, and T.N. Kaye. 2011. Management strategies for invasive plants in Pacific Northwest prairies, savannas, and oak woodlands. Northwest Science 85: 329-351. doi: 10.3955/046.085.0219

Dibble, A.C., R.H. White, and P.K. Lebow. 2007. Combustion characteristics of north-eastern USA vegetation tested in the cone calorimeter: invasive versus non-invasive plants. International Journal of Wildland Fire 16: 426-443. doi: 10.1071/WF05103

Dimitrakopoulos, A.P., I.D. Mitsopoulos, and K. Gatoulas. 2010. Assessing ignition probability and moisture of extinction in a Mediterranean grass fuel. International Journal of Wildland Fire 19: 29-34. doi: 10.1071/WF08124

Engber, E.A., and J.M. Varner. 2012. Reversing conifer encroachment with prescribed fire: shifting mortality models toward restoration targets. Restoration Ecology 20: 665-668. doi: 10.1111/j.1526-100X.2012.00900.x

Engber, E.A., J.M. Varner, L. Arguello, and N. Sugihara. 2011. The effects of conifer encroachment and overstory structure on fuels and fire in an oak woodland landscape. Fire Ecology 7(2): 32-50. doi: 10.4996/fireecology.0702032

Fritschle, J.A. 2008. Reconstructing historic ecotones using the public land survey: the lost prairies of Redwood National Park. Annals of the Association of American Geographers 98: 2439. doi: 10.1080/00045600701734018

Grenier, K.H. 1989. Vegetation patterns in grasslands of Redwood National Park, California. Thesis, Humboldt State University, Arcata, California, USA.

Hastings, M.S., S. Barnhart, and J.R. McBride. 1997. Restoration management of northern oak woodlands. USDA Forest Service General Technical Report PSW-GTR-160, Pacific Southwest Research Station, Albany, California, USA.

Hitchcock, A.S. 1971. Manual of the grasses of the United States. Dover, Mineola, New York, USA.

Hosten, P.E., O.E. Hickman, F.K. Lake, F.A. Lang, and D. Vesely. 2006. Oak woodlands and savannas. Pages 63-96 in: D. Apostol and M. Sinclair, editors. Restoring the Pacific Northwest: the art and science of ecological restoration in Cascadia. Island Press, Washington, D.C., USA. 
Livingston, A.C. 2014. Plant community responses to fire exclusion, species invasions, and restoration in California woodlands and grasslands. Thesis, Humboldt State University, Arcata, California, USA.

Loomis, R.M., P.J. Roussopoulos, and R.W. Blank. 1979. Summer moisture contents of understory vegetation in northeastern Minnesota. USDA Forest Service Research Note NCRN-179, North Central Experiment Station, St. Paul, Minnesota, USA.

Mack, M.C., and C.M. D'Antonio. 1998. Impacts of biological invasions on disturbance regimes. Trends in Ecology and Evolution 13: 195-198. doi: 10.1016/S0169-5347(97)01286-X

McDonald, C.J., and G.R. McPherson. 2013. Creating hotter fires in the Sonoran Desert: buffelgrass produces copious fuels and high fire temperatures. Fire Ecology 9(2): 26-39. doi: 10.4996/fireecology.0902026

McGranahan, D.A., D.M. Engle, J.R. Miller, and D.M. Debinski. 2013. An invasive grass increases live fuel proportion and reduces fire spread in a simulated grassland. Ecosystems 16: 158-169. doi: 10.1007/s10021-012-9605-4

Platt, W.J., and R.M. Gottschalk. 2001. Effects of exotic grasses on potential fine fuel loads in the groundcover of south Florida slash pine savannas. International Journal of Wildland Fire 10: 155-159. doi: 10.1071/WF01016

Rice, C. 1989. Live fuel moisture sampling methods for Chiricahua National Monument. Cooperative National Park Resources Studies Unit, University of Arizona Technical Report No. 27, Tucson, Arizona, USA.

Saenz, L. 1983. Quercus garryana woodland/grassland mosaic dynamics in northern California. Thesis, Humboldt State University, Arcata, California, USA.

Saenz, L., and J. Sawyer. 1986. Grasslands as compared to adjacent Quercus garryana woodland understories exposed to different grazing regimes. Madroño 33: 40-46.

Setterfield, S.A., N.A. Rossiter-Rachor, M.M. Douglas, L. Wainger, A.M. Petty, P. Barrow, I.J. Shepard, and K.B. Ferdinands. 2013. Adding fuel to the fire: the impacts of non-native grass invasion on fire management at a regional scale. PLoS ONE 8: e59144. doi: 10.1371/journal. pone.0059144

Stanley, A.G., P.W. Dunwiddie, and T.N. Kaye. 2011. Restoring invaded Pacific Northwest prairies: management recommendations from a region-wide experiment. Northwest Science 85: 233-246. doi: 10.3955/046.085.0212

Sugihara, N.G., and L.J. Reed. 1987. Vegetation ecology of the Bald Hills oak woodlands of Redwood National Park. Redwood National Park Research and Development Technical Report Number 21, Arcata, California, USA.

Sugihara, N.G., L.J. Reed, and J.M. Lenihan. 1987. Vegetation of the Bald Hills oak woodlands, Redwood National Park, California. Madroño 34: 193-208.

Tveten, R.K., and R. Fonda. 1999. Fire effects on prairies and oak woodlands on Fort Lewis, Washington. Northwest Science 73: 145-158.

Underwood, S., L. Arguello, and N. Siefkin. 2003. Restoring ethnographic landscapes and natural elements in Redwood National Park. Ecological Restoration 21: 278-283. doi: 10.3368/ er.21.4.278

USDI [US Department of the Interior] Redwood National Park. 1992. Bald Hills vegetation management plan. Redwood National Park, Orick, California, USA.

Zar, J.H. 1999. Biostatistical analysis. Third edition. Prentice-Hall, Upper Saddle River, New Jersey, USA. 